\title{
PENGUATAN KOMPETENSI GURU DALAM MENDESAIN MEDIA PEMBELAJARAN INTERAKTIF DENGAN PROGRAM AUTOPLAY DI MI AL-IKHLASIYAH PERAMPUAN
}

\author{
Nuruddin \\ Dosen Prodi. PGMI, UIN Mataram \\ nuruddinmsi@uinmataram.ac.id
}

\begin{abstract}
Abstrak: media memiliki peran vital dan strategis dalam memastikan praktek pembelajaran berjalan dengan baik. Pengabdian ini dilakukan dengan tujuan untuk membantu mengembangkan dan menguatkan kompetensi guru. Salah satu bentuk penguatan kompetensi tersebut adalah dengan pelatihan guru mendesain media pembelajaran interaktif dengan program Autoplay. Pelatihan ini dilaksanakan dalam lima tahapan yaitu; (1) Observasi Dan Pengenalan Madrasah; (2) Sosialisasi Program dan FGD; (3) Pelatihan mendesain media pembelajaran dengan software autoplay; (4) Pendampingan penguatan guru dalam pembelajaran dengan software autoplay tahap pertama; (5) Pendampingan penguatan guru dalam pembelajaran dengan software autoplay tahap kedua; (6) monitoring evaluasi. Hasil pengabdian menunjukkan bahwa terjadi perubahan mindset guru tentang inovasi pembelajaran ditambah lagi dengan peningkatan kemampuan guru dalam membuat media pembelajaran dengan software autoplay.

Hasil kegiatan Pengbdian menunjukkan bahwa pengetahuan guru dalam mengoperasikan program tersebut semakin mengalami peningkatan dan dapat dimanfaatkan, dipraktikkan sebagai media pembelajaran di dalam kelas.
\end{abstract}

Kata Kunci: Kompetensi Guru, media interaktif, autoplay.

\section{PENDAHULUAN}

Kemajuan ilmu pengetahuan dan teknologi (IPTEK) dewasa ini memberikan informasi tentang pesatnya perubahan sosial masyarakat termasuk dibidang pendidikan. Pendidikan sebagai akar pengokoh kemajuan generasi bangsa memberikan kontribusi dalam mendidik generasi bangsa yang produktif dan partisipatif. Produktif dengan usaha-usaha pengembangan diri dan partisipatif dalam pembangunan bangsa.

Salah kebutuhan yang harus dipenuhi untuk menjamin kualitas pembelajaran yang baik adalah dengan teknologi pendidikan. "...Educational technology is was used to describe a subset of education which was involved in solving problems related to all aspect of human learning through complex, 
interrelated processes ${ }^{18}$. Berdasarkan definisi tersebut, teknologi pendidikan dalam hal ini digunakan untuk menggambarkan bagian dari pendidikan dalam menyelesaikan persoalan-persoalan yang berkaitan dengan semua aspek pembelajaran manusia, yang kompleks dan saling terkait.

Saat ini paradigma pendidikan dan pengajaran telah mengalami pergeseran, yakni dari pengajaran yang berpusat pada guru (teacher centered) menjadi pengajaran yang berpusat pada peserta didik (student centered). Pergeseran paradigma ini secara tidak langsung akan menuntut tersedianya sarana dan prasarana belajar yang memadai dalam rangka memberikan peluang bagi peserta didik untuk dapat belajar secara mandiri. Perkembangan Teknologi informasi dan komunikasi (TIK) saat ini dapat menjadi faktor pendukung terlaksananya belajar secara individual.

Di sisi lain, penggunaan TIK dalam kegiatan pembelajaran, dapat menjadi salah satu faktor penting yang memungkinkan kecepatan transformasi ilmu pengetahuan kepada peserta didik secara lebih luas ${ }^{9}$. Peserta didik yang tumbuh di era digital saat ini cendrung lebih mudah mengakses informasi dari berbagai media, sehingga hal ini berdampak pada cara mereka berinteraksi dan menggunakan informasi itu sendiri ${ }^{10}$.

Dalam kegiatan pembelajaran, adanya teknologi yang canggih menjadikan sumber informasi tidak lagi terfokus pada teks dari buku semata, akan tetapi sudah lebih luas dari itu. Sekarang ini untuk mengakses informasi belajar, peserta didik dapat menggunakan sumber terbuka (open source), dapat melalui media internet maupun bentuk-bentuk multimedia berbasis komputer lainnya. Pengaplikasian kegiatan pembelajaran secara langsung berdampak pada peningkatan kualitas proses belajar mengajar menjadi lebih efektif dan efisien,

8 Seels, B.B. \& Richey, R.C. Teknologi Pembelajaran: Definisi dan Kawasannya (terjemahan). (Washington DC: AECT, 1994). h. 4.

${ }^{9}$ Deni Darmawan, Teknologi Pembelajaran. (Bandung: PT. Remaja Rosdakarya, 2011), h.14.

${ }^{10}$ Ruth Geee \& Trudy-Ann Sweeney. Students' Voices about Learning with's Technology. Journal of Social Sciences, 8 (2), hh. 294-303. 
terutama teknik, pendekatan, strategi dan metode yang digunakan ketika kegiatan pembelajaran berlangsung, baik di dalam kelas, maupun di luar kelas ${ }^{11}$.

Komputer memberi peranan yang baru bagi guru. Ia harus bekerjasama dengan para ahli lain yang bertalian dengan komputer dalam memprogram pelajaran ${ }^{12}$. Oleh karena itu penggunaan komputer pada dunia pendidikan menuntut guru untuk memiliki kompetensi lain diluar kompetensinya sebagai seorang guru.

TIK memiliki peran vital dalam pengembangan sistem pendidikan. "...to use of ICT academic level in the school has increased ${ }^{\prime 13}$. Dari kutipan tersebut bahwa penerapan TIK dalam pembelajaran disetiap level akademis mengalami peningkatan. Inilah yang menandai betapa pentingnya menerapkan TIK dalam pembelajaran. Disamping memudahkan guru dalam mengajar, penggunaan TIK juga sangat dirasakan manfaatnya oleh semua pihak yang ada dalam lingkungan sekolah dimana TIK digunakan.

Pengolahan informasi dan pendistribusiannya melalui jaringan telekomunikasi membuka banyak peluang untuk dimanfaatkan di berbagai bidang kehidupan manusia, komputer memungkinkan siswa untuk belajar sesuai dengan kecepatan dan kemampuannya. Memahami materi yang ditayangkan ${ }^{14}$, komputer dapat mengkombinasikan warna, musik dan animasi grafik. termasuk salah satunya membuat simulasi animasi sebagai media pembelajaran.

Sebagai media pembelajaran, peran komputer menjadi salah satu sumber utama (major resources) dalam mengimplementasikan program pembelajaran di sekolah, melalui komputer siswa dapat menjalankan aplikasi program yang didukung juga dengan fasilitas penunjang lain yang saat ini berkembang yaitu

${ }^{11}$ Ansori, Multimedia Interaktif dalam Pembelajaran Ilmu Pengetahuan Sosial (IPS). Jurnal Jurusan Pendidikan IPS Ekonomi Society Edisi VII (Mataram: Fakultas Tarbiyah IAIN Mataram, 2012), h. 59.

${ }_{12}$ Nasution, Teknologi Pendidikan, (Jakarta, Bumi Aksara: 2012), h. 112

${ }^{13}$ TOSUN Nilgün. Using Information and Communication Technologies in School Improvement. TOJET: The Turkish Online Journal of Educational Technology Volume 10 Issue 1 (2011), hh. 223-231.

${ }^{14}$ Rusman, Belajar dan Pembelajaran Berbasis Komputer, (Bandung: Al-Fabeta, 2013), h. 
intenet ${ }^{15}$. Penggunaan komputer sebagai media pembelajaran sangat beragam diantaranya adalah powepoint, flash, dan Autoplay dan lain sebagainya.

Berdasarkan hasil studi pendahuluan, di MI Al-Ikhlasiyah Perampuan sudah melaksanakan pembelajaran dengan menggunakan komputer namun belum maksimal, biasanya menggunakan powerpoint. Hampir semua guru dapat mengoperasikan komputer, tetapi tidak semua guru dapat membuat media presentasi menarik yang dapat menimbulkan perhatian dan ketertarikan siswa. Pemanfaatan komputer dalam pembelajaran menarik untuk materi tertentu, artinya tidak semua materi dapat menggunakan komputer dalam pembelajaran. Selama ini, belum ada pelatihan khusus tentang pengembangan soft skill guru dalam mendesain presentasi menarik.

Berdasarkan latar persoalan di atas dianggap perlu dilakukan pelatihan guru tentang bagaimana mendesain media presentasi interaktif yang dapat menciptakan pembelajaran yang menarik dan tidak membosankan dengan judul "Penguatan Kompetensi Guru dalam Mendesain Media Pembelajaran Interaktif Dengan Program Autoplay di MI Al-Ikhlasiyah Perampuan".

\section{PEMBAHASAN}

Setiap pekerjaan yang bermanfaat untuk memudahkan seseorang selalu membutuhkan media untuk mempermudah proses pengerjaannya. Seorang petani yang hendak membajak sawah tentu menggunakan traktor sebagai media untuk mempermudah pekerjaannya. Seorang dokter yang hendak mendiagnosis penyakit pasiennya tentu membutuhkan media dan alat untuk mendeteksinya. Demikian juga profesi seorang guru yang baik dan profesional membutuhkan media pembelajaran yang baik dalam mempermudah penyampaian materi pembelajarannya.

Media adalah segala sesuatu yang dapat digunakan untuk menyalurkan pesan dari pengirim kepenerima sehingga merangsang pikiran, perhatian, dan minat serta kemauan peserta didik sedemikian rupa sehingga proses belajar

${ }^{15}$ Ibid, h. 128-129 
terjadi dalam rangka mencapai tujuan pembelajaran secara efektif ${ }^{16}$. Media pembelajaran adalah segala sesuatu yang dapat digunakan untuk menyalurkan pesan dari pengirim kepenerima sehingga dapat merangsang pikiran, perasaan, perhatian dan minat serta perhatian siswa sedemikian rupa sehingga proses belajar terjadi ${ }^{17}$.

Untuk pembiasaan guru dalam pemanfaatan media pembelajaran, dibutuhkan keterlibatan semua pihak, termasuk perguruan tinggi. Implementasi dari tugas tridharma perguruan tinggi, salah satunya adalah pengabdian. Pengbdian merupakan satu dari dari tiga tugas tridharma perguruan tinggi selain dibidang pendidikan dan penelitian. Tugas ini adalah tugas wajib yang harus dilakukan oleh seorang dosen dengan tujuan pengabdian kepada Negara melalui upaya peningkatan kualitas pendidikan dan pengajaran madrasah.

Berikut tahapan-tahapan selama pengabdian; (1) observasi dan pengenalan madrasah, (2) Sosialisasi dan Focus Group Discussion, (3) Pelatihan mendesain media pembelajaran dengan software autoplay (4) Pendampingan penguatan guru dalam pembelajaran dengan software autoplay tahap pertama, (5) penguatan guru dalam pembelajaran dengan software autoplay tahap kedua, (6) Monitoring Evaluasi. Keenam tahapan di atas dilakukan secara sistematis dan terukur. Untuk lebih jelasnya kegiatan di setiap tahapan tersebut di jelaskan lebih detail di bawah ini:

\section{Observasi Dan Pengenalan Madrasah}

Observasi merupakan cara pengumpulan data yang dilakukan secara sistematis. Observasi dilakukan menurut prosedur dan aturan tertentu sehingga dapat diulangi kembali oleh peneliti dan hasil observasi memberikan kemungkinan untuk ditafsirkan secara ilmiah. Observasi merupakan metode pengumpulan data yang menggunakan pengamatan terhadap obyek penelitian. ${ }^{18}$

Observasi ada dua macam yaitu observasi langsung dan tidak langsung yaitu: (1) Teknik Observasi Langsung dimana observasi yang mengadakan

\footnotetext{
${ }^{16}$ Sukiman, Pengembangan media pembelajaran, (Yogyakarta: Pedagogia, 2012), h. 29.

17 Sardiman, Interaksi dan motivasi belajar mengajar, (Jakarta: PT Raja Grafindo Persada, 2012), h. 7

${ }^{18}$ Yatim Riyanto, Metodologi Penelitian Pendidikan (Surabaya: SIC, 2001), hal 96
} 
pengamatan secara langsung (tanpa alat) terhadap gejala-gejala subyek yang diselidiki, baik pengamatan itu dilakukan di dalam situasi sebenarnya maupun dilakukan di dalam situasi buatan yang khusus diadakan. ${ }^{19}$ Jadi, observasi ini merupakan salah satu proses pengamatan dalam penelitian eksploratif yang observer langsung ambil bagian dalam keadaan obyek yang diobservasi. (2) Teknik Observasi Tak Langsung mengadakan pengamatan terhadap gejalagejala subyek yang diselidiki dengan perantara sebuah alat, pelaksanaannya bisa berlangsung dalam situasi sebenarnya maupun di dalam situasi buatan. ${ }^{20}$

Media yang dipahami secara garis besar adalah manusia, materi, atau kejadian yang membuat siswa mampu memperoleh pengetahuan, keterampilan atau sikap. Media dalam perspektif ini tidak dibatasi sebagai upaya untuk mempermudah penyampaian materi pelajaran tapi menyangkut peristiwa yang terjadi dalam penyampaian materi pembelajaran. Media pembelajaran adalah segala sesuatu yang mempermudah guru dalam menyampaikan materi pembelajaran dan dapat memfokuskan perhatian, minat peserta didik untuk belajar agar penyampaian materi ajar menjadi lebih kongkrit. Dengan demikian, tujuan pemanfaatan media pembelajaran adalah untuk mengefektifkan dan mengefesienkan proses pembelajaran itu sendiri ${ }^{21}$.

Berdasarkan hasil observasi dapat diinformasikan tentang proses kegiatan belajar mengajar di dalam kelas masih menggunakan metode pembelajaran konvensional, artinya pembeljaran masih mengedepankan interaksi antara guru dan murid dengan kurang memperhatikan peran media pembelajaran. Sebagian besar guru sudah memiliki keterampilan mengoperasikan komputer. Namun tidak semua guru melaksanakan pembelajaran berbasis komputer. Komputer bukan barang langka yang sulit diperoleh dan susah dioperasikan.

Tentang fasilitas yang mendukung pembelajaran cukup memadai, namun ada beberapa fasilitas yang belum mendukung yaitu LCD Proyektor. Keberadaan LCD menjadi penghambat utama proses diseminasi dalam penyeragaman

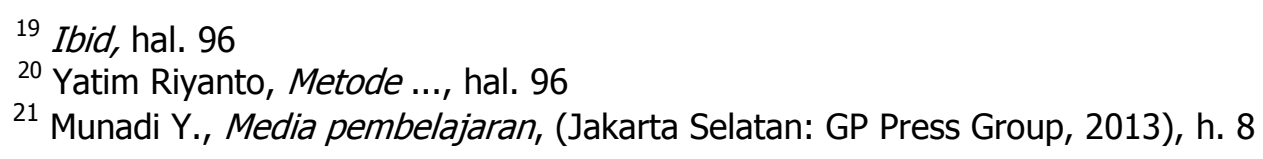


pengetahuan guru tentang teknologi. Walaupun demikian, secara tidak langsung sudah banyak menjalankan aktivitas berbasis komputer tidak dalam proses pembelajaran. Sehingga walaupun begitu, tidak menjadi sulit untuk mengembangkan proses pembelajaran berbasis komputer.

\section{Sosialisasi Program dan FGD}

Sosialisasi adalah sebuah konsep tentang proses dimana kita dapat belajar melalui interaksi dengan orang lain, tentang cara berfikir, merasakan dan bertindak dimana kesemuanya penting dalam menghadirkan partisipasi sosial yang efektif.

Langkah selanjutnya setelah observasi adalah sosialisasi melalui kegiatan Focus Group Discussion (FGD). Sebelum kegiatan pelatihan dan pengembangan dilakukan, biasanya diawali dengan sosialisasi atau orientasi. Sosialisasi adalah merupakan proses yang mengacu pada persiapan pengajaran tentang bagaimana melakukan usaha, termasuk bagaimana memahami dan menerima nilai-nilai, norma, dan keyakinan.

Sosialisasi adalah upaya yang dilakukan pengabdi untuk mengkomunikasikan program yang akan dilaksanakan selama proses pengabdian di Madrasah. Kegiatan ini dilakukan melalui kunjungan awal ke Kepala MI Al-Ikhlasiyah Perampuan, kemudian dalam kesempatan yang sama juga dihadiri oleh guru-guru. Beberapa agenda yang sudah dipersiapkan pada kegiatan sosialisasi adalah menjelaskan dan meyakinkan guru tentang urgensi media pembelajaran dalam memudahkan guru menyampaikan pesan-pesan pembelajaran tersampaikan dengan baik. Kedua adalah memberikan informasi bagi guru untuk dapat menggunakan media pembelajaran berbasis komputer. Jika selama ini media presentasi banyak menggunakan powerpoint, maka pada kesempatan ini pengabdi banyak memberikan penjelasan tentang media pembelajaran dengan software autoplay.

Setelah mendengar penjelasan fasilitator, autoplay adalah benda baru yang masih dianggap asing. Autoplay memang tidak pernah digunakan sebagai media pembelajaran, bahkan autoplay ini baru di dengar secara langsung namanya dari pengabdi itu sendiri. Guru sangat antusias dengan penjelasan guru. Melalui 
program ini banyak hal yang ingin dieksplorasi, terutama strategi mendesain program pembelajaran berbasis software autoplay.

Pada kesempatan FGD, beberapa guru memberikan pertanyaan tentang bagaimana strategi belajar mengajar yang baik agar lebih cepat memahami program tersebut. Pada kesempatan tersebut, pengabdi memberikan respon positif bahwa kegiatan ini nantinya tidak akan dilepas begitu saja melainkan akan diberikan pendampingan. Guru yang lain juga menyampaikan aspirasinya tentang kondisi yang tidak memungkinkan untuk mengikuti pelatihan semisal belum memiliki notebook. Tentang hal ini pengabdi menjelaskan bahwa kegiatan ini tidak dipaksakan semua guru memiliki notebook, akan tetapi satu notebook dapat digunakan untuk dua orang secara bersam-sama. Pelaksanaan kegiatan sosialisasi dan FGD berjalan lancar. Kegiatan ini memunculkan beberapa kesepakatan diantaranya tentang kegiatan pelatihan. Kegiatan FGD dan sosialisasi dihadiri oleh 20 orang guru.

\section{Pelatihan mendesain media pembelajaran dengan software autoplay}

Sebelum kegiatan pelatihan dimulai, kegiatan diawali dengan pembukaan yang disambut dan dibuka oleh pimpinan yayasan. Dalam sambutannya, pimpinan yayasan menyampaikan ucapan terima kasih yang sebenarnya atas kesediaan fasilitaor melaksanakan pengabdian ditempatnya dan berharap kegiatan ini berkelanjutan karena program ini berkaitan langsung dengan program pemberdayaan SDM guru.

Sumber daya manusia sebagai aset terpenting, memiliki peran strategis dalam menghadapi persaingan global. Kualitas dan kompetensi anggota organisasi dapat dijadikan sebagai alat untuk meraih keunggulan kompetitif (competitive advantage) dan membawa kesuksesan organisasi.

Kesuksesan organisasi diperoleh melalui program pelatihan dan pengembangan secara efektif keunggulan kompetitif satu organisasi sekolah. Dalam lingkungan persaingan yang semakin ketat, program pelatihan dan pengembangan tidak lagi sebagai suatu pilihan, tetapi sudah merupakan suatu kebutuhan. 
Guru memiliki peran strategis dalam proses belajar mengajar. Guru mempersiapkan peserta didik menjadi warga yang produktif, berfikir kritis tentang masyarakat dan kehidupannya, membangun karakter dan berjiwa sosial. Peran itu melekat pada tugas dan fungsi guru yang harus dijalankan sebaikbaiknya, bukan karena kurangnya ketersediaan lapangan kerja melainkan karena cita-cita, minat dan bakat serta rasa senangnya terhadap dunia pendidikan.

Integrasi TIK dalam pembelajaran adalah permasalahan yang kerap muncul dalam dunia pendidikan. Tingginya kemampuan seorang guru dalam TIK belum menjamin guru tersebut dapat mengintegrasikan TIK dengan baik dalam pembelajaran. Pada bagian ini akan diungkapkan apakah guru telah mengintegrasikan TIK dalam pembelajaran. Untuk itu dilakukan pelatihan guru.

Pelatihan guru dilakukan dengan tujuan untuk Untuk meningkatkan ketrampilan sesuai sesuai dengan perubahan dan perkembangan teknologi, mengawal kompetensi guru dalam masalah operasional, dan menguatkan kompetensi guru dalam pengembangan profesinya.

Kompetensi guru harus senantiasa di-upgrade kapanpun saja. Lebih-lebih diera dewasa ini, perkembangan teknologi informasi semakin berkembang. Kalau tidak maka wawasan guru akan jauh tertinggal dibandingkan siswanya. Apalagi kebutuhan siswa juga makin berkembang. Namun diera dewasa ini, banyak guru yang mengalami tugas yang memprihatinkan.

Autoplay adalah software yang disiapkan untuk membantu guru mendesain media pembelajaran. Kegiatan pelatihan dihadiri oleh guru MI A-Al-Ikhlasiyah Perampuan sejumlah 20 Orang. Masing-masing guru terbagi dalam guru mata pelajaran, guru kelas dan kepala madrasah.

Guru dengan serius mengikuti kegiatan pelatihan. Pada kesempatan ini banyak guru yang butuh pendampingan secara khusus. Karena ada juga sebagian guru yang belum dapat dengan cepat meniru aktivitas peserta. Kesiapan guru dalam mengikuti program pelatihan ditunjukkan dengan kehadiran guru yang rata-rata siap. Pada pemapaannya narasumber menampilkan layar proyektor di tembok. Selanjutnya dilakukan simulasi tentang 
bagaimana mengoperasikan dan mendesain media pembelajaran dengan media autoplay.

Penyampaian materi autoplay melalui simulasi memberikan kemudahan bagi guru dalam melaksanakan pembelajaran. Guru mengeksplorasi secara mendalam tentang materi yang diajarkan. Guru juga banyak bertanya manakala terdapat kesulitan-kesulitan yang dilalui saat memberikan simulasi pembelajaran.

Dalam pemaparannya, narasumber banyak menjelaskan tentang bagaimana membuat button dan menggantinya sesuai dengan apa yang diinstruksikan. Pengenalan fitur menu autoplay dimulai dari mengenal menu file, edit, dan lain sebagainya. Langkah selanjutnya adalah Setelah halaman Home dibuat, langkah selanjutnya adalah mendesain halaman Home dengan memberikan tombol-tombol. Tombol ini digunakan untuk menghubungkan halaman Home dengan halaman-halaman lain. Untuk membuat tombol klik icon new button object pada toolbar.

Pelatihan tidak cukup sampai hal di atas, selanjutnya adalah membuat properties. Properties adalah panel yang memuat properties/ keterangan yang ada dalam Prospect, mengenalkan projek eksplorer, project size, kemudian install. Setelah aplikasi autoplay sudah teinstall dengan baik, selanjutnya buka file instalasi dan jalankan. Langkah berikutnya Klik/buka folder autplay yang tampil di jendela widows seperti gambar sebelumnya, sehingga muncul seperti gambar di bawah ini. Lalu klik kanan Aplikasi ams70ev (lihat tanda panah). Setelah klik kanan pilih Run Administrator, Setelah klik Run Administrator akan muncul tampilan seperti gambar, pilih/klik next untuk melanjutkan proses instalasi. Setelah klik next pada step sebelumnya, kemudian akan muncul wizard License Agreement dan klik next untuk melanjutkan. Sampai pada Setelah selesai proses instalasi, buka aplikasi di All Application, atau temukan di dekstop.

Untuk memproduksi multimedia dan membuat projek baru, guru dapat Klik create a new Prospect, Masukkan nama project > klik blank project $>$ klik create project now, Tampilan awal project yang anda kehendaki. Sedangkan untuk memberi judul Projek dapat dilakukan dengan Pilih Project > Settings, Ubah window title dengan nama "Multimedia Interaktif" dan pilih "Always on top". 
Ketik Page size ukuran lebar 800 dan tinggi 600. Klik OK untuk menutup jendela dialog, Pilih Publish > Preview, lalu Klik tombol close di title bar untuk keluar dari preview.

Untuk menambahkan halaman baru, klik kanan pada Page Tab, kemudian klik Add. Dan Akan tampil halaman tab baru. Untuk mengatur halaman, Pada properties pane, klik Page, Untuk memberikan judul halaman, letakkan kursor di kolom "Name" kemudian tulis judulnya misalkan "Beranda". Untuk Mengatur Background Halaman sesuai dengan keinginan. Jika ingin menggunakan background warna, misalkan warna biru muda (\#99CCFF). Klik Select button, Pilih warna background, Jika ingin mengubah background style dari warna solid menjadi gradien, maka klik background Style, klik select Button, pilih gradient. Baground dapat dipilih berdasarkan keinginan dari guru sendiri.

Memulai insert Buton dan Action Buton diawali dengan Pilih Object > Button untuk menambahkan Buton, Pada saat dialog Select File muncul, klik Gallery button. Pilih file (misal green_pill.btn) dan klik OK, Untuk menyetting button, aktifkan Button, klik Properties Pane. Setting, sesuai dengan kebutuhan (misalkan text, font, alignment, colours), klik kanan pada button kemudian klik properties, Ketik keterangan button pada kolom Text, misalnya akan membuat buttonVideo ketik "VIDEO".

Untuk menambahkan Action Button dapat mengikuti langkah dibawah ini: Pada Page Surface, klik button yang akan ditambahkan Action Button (missal button1 "BERANDA"), Pastikan kategori Actions terbuka dalam properties Pane, Klik pada setting On Click, kemudian klik tombol edit untuk membuka script editor, Klik tombol edit sehingga akan membuka script editor, dimana kita bisa menambahkan action untuk tiap even dari objek. Klik tombol Add Action. Pada saat New Action Wizard muncul, ubah kategori aplikasi kemudian klik action pada setep 2 yang disebut Page.Jump. Kemudian Klik OK. Di Step 3, dalam PageName pilih halaman yang dituju saat button diklik. Misalkan button1 "BERANDA" mengarahkan ke halaman "BERANDA". Kemudian Klik Finish > OK. 
Untuk membuat exit button, menggunakan cara yang sama dengan membuat action button namun pada step 2 dipilih Application.Exit. pelatihan ini semakin menantang kegiatan guru. Guru semakin tertarik untuk dapat memahami program yang sudah dibuat guru. Namun pada kesempatan ini guru belum dapat menyelesaikan materi pelatihan, dan diharapkan selanjutnya guru dapat dipandu pembelajarannya melalui modul yang sudah disiapkan guru.

\section{Pendampingan penguatan guru dalam pembelajaran dengan software autoplay tahap pertama}

Pendampingan berfungsi untuk memantau sejauh mana penyerapan guru selama pelatihan, membantu guru menyelesaikan persoalan selama pelatihan, berbagi pengalaman dan membantu guru lebih aktif dalam mempelajari program autoplay, berbagi pendapat dan kemitraan, meningkatkan kualitas dan profesionalisme guru, dan secara bersama-sama mengevaluasi proses pembelajaran yang lebih baik.

Pendampingan adalah pemberian bantuan teknis tentang penyampaian dan penguatan materi sebelumnya. Materi pendampingan tidak jauh berbeda dengan materi saat pelatihan. Materinya menyangkut tentang hal-hal yang belum dipahami oleh guru selama melaksanakan praktikum.

Kegiatan pendampingan dilakukan oleh fasilitator. Adapun sasaran pendampingan adalah semua guru yang pernah mengikuti pelatihan mendesain media pembelajaran dengan autoplay. Adapun tujuan pendampingan adalah untuk: (1) Memperkuat pemahaman dan membangun kepercayaan diri unsur-unsur sekolah dalam melaksanakan pembelajaran; (2) memperkuat keterlaksanaan pembelajaran yang fleksibel; (3) Membantu memberikan solusi kontekstual dalam menyelesaikan permasalahan yang dihadapi mendesain media pembelajaran; (4) Membangun kultur belajar sekolah melalui penerapan kurikulum secara inovatif, kontekstual, taat asas, dan berkelanjutan.

Kegiatan pendampingan dihadiri Loe 20 peserta. Adapun materi pendampingan mencakup penguatan keterampilan guru tentang bagaimana 
memasukkan gambar, menduplikasi halaman, insert teks dan label, insert paragraf, insert audio, menambahkan baground musik dan lain sebagainya.

Untuk menambahkan audio, dapat dilakukan dengan Pilih Object > Video, Pada saat kotak dialog muncul, pilih video yang akan ditambahkan. Format file video .mpg/.mpeg lalu klik OK, Pada "Properties" (terletak disamping kiri bawah area kerja), ubah setting pada "Control Panel", Jika ingin mengubah style tampilan tombol contro/video. Pada "Contro/Style", pilih Basic Blue dengan cara klik tanda panah ke bawah. Adapun untuk menambahkan kontrol video dapat dilakukan dengan Seleksi objek video. Pada properties pane, atur ControlStyle menjadi "None", Buat button menggunakan file grey_pill.bth, kemudian pada properties pane ubah width 55 dan height 27. Ubah font menjadi Verdana, dan front size 8. Atur Bold dan Italic "True". Isi teks pada button "PLAY" dan atur YOffset 1, Klik tombol PLAY, tekan Ctrl+D untuk duplikasi menjadi 3 button. Ubah teks menjadi PAUSE dan STOP

Membuat dan insert kuis menggunakan quiz creator dilakukan dengan langkah dibawah ini Klik Create New Quiz, Untuk memilih model tampilan atau template, klik Player Template, Ada banyak pilihan jenis soal. Lakukan double klik salah satu untuk menentukan jenis soal. Jenis soal dapat dicampur dari berbagai jenis soal MEMBUAT QUIZ. Untuk menyimpan quiz dilakukan dengan Klik Save (gambar disket), Pilih Drive dan Folder tempat anda menyimpan file, kemudian klik Save. Sedangkan untuk mengatur Mengatur quiz propertiez (model quiz) dilakukan dengan langkah berikut ini Klik Quiz Properties, Quiz Information berfungsi untuk menuliskan information tentang quiz, dan seterusnya.

Setelah penguatan melalui pendampingan program di atas langkah terakhir adalah bagaimana mempublish lembar kerja menjadi produk dari autoplay itu sendiri. Melakukan publishing/ finishing quiz creator agar Quiz Creator dapat digunakan oleh peserta didik/ siswa. Langkah-langkahnya sebagai berikut: Klik Publish, Klik CD/EXE, dan publish dan mencoba hasil quiz. 


\section{Pendampingan penguatan guru dalam pembelajaran dengan software autoplay tahap kedua.}

Pendampingan ini dilaksanakan tidak melalui pengadaan pelatihan namun lebih kepada proses yang dilalui oleh guru selama melaksanakan pelatihan. Kesepakatan pendampingan tahap pertama sudah disepakati sebelumnya. Yaitu bertujuan untuk memperbaiki hasil pada tahap pertama, semua tahapan dilakukan dengan prinsip kesejawatan, kepercayaan, keterbukaan, terarah dan antusias tanpa ada maksud untuk menggurui. Pada kesempatan ini tidak melakukan pendampingan secara teknis, namun lebih kepada membuat pemahaman yang sama tentang penilaian antar masingmasing guru, membangun kemitraan yang sinergis antara pendamping dan terdamping.

Beberapa kondisi yang terjadi saat pendampingan adalah sikap keterbukaan antar guru. Guru tidak pernah berhenti untuk belajar, siapapun yang menjadi fasilitator guru MI Al-Ikhlasiyah dengan sangat ramah-tamah menghargai dan menyambut tim pengabdi dengan suasana yang hangat tanpa ada unsur paksaan dalam mengikuti program pendampingan. Kondisi ini juga tidak terlepas dari sikap dan perilaku pendamping yang ramah dengan semua guru, yang memberi penekanan pada penguatan kekuatan bukan mengajarinya. Pendamping tidak merasa pada posisi yang lebih tinggi melainkan mau dan mampu berbaur dengan guru secara ikhlas dan merasa menjadi bagian dari keluarga.

Kegiatan pendampingan selama dua kali diawali dari kegiatan: (1) memberi motivasi, memuji dan memberikan penguatan; (2) menyampaikan perkembangan positif selama pelatihan dan pendampingan tahap pertama lalu disusul dengan kekeurangan; (3) menganalisis secara bersama-sama tentang kesulitan yang dihadapi dan menyelesaikannya secara bersama-sama; (4) menemukan masalah lainnya. Yang pada akhirnya antara pendamping dan terdamping tidak ada jarak antara keduanya. 


\section{Evaluasi program pelatihan}

Evaluasi adalah rangkaian kegiatan membandingkan realisasi masukan (input), keluaran (output), dan hasil (outcome) terhadap rencana dan standar. Evaluasi merupakan merupakan kegiatan yang menilai hasil yang diperoleh selama kegiatan pemantauan berlangsung. Lebih dari itu, evaluasi juga menilai hasil atau produk yang telah dihasilkan dari suatu rangkaian program sebagai dasar mengambil keputusan tentang tingkat keberhasilan yang telah dicapai dan tindakan selanjutnya yang diperlukan.

Evaluasi dilakukan bersama kepala sekolah guru dan staf akademik lainnya. Evaluasi dilakukan untuk mengetahui kelemahan dan kekuatan program pengabdian. Kelemahan tersebut dijadikan sebagai pedoman untuk melaksanakan pengabdian di kemudian hari. Sejauh ini hasil evaluasi menghasilkan beberapa temuan diantaranya perlu ada penguatan dan tindak lanjut tentang pelatihan program autoplay di sekolah ini. Program ini dijadikan sebagai salah satu media komunikatif yang ramah anak, inovatif dan menyenangkan.

Dalam pertemuan ini, guru menyampaikan ucapan terima kasih atas ilmu yang sudah diajarkan dan memohon maaf manakala dalam proses pelatihan terdapat kekurangan yang menyebabkan kelancaran kegiatan terhambat. Demikian pula fasilitatorpun menyampaikan ungkapan terima kasih atas kesempatan yang baik dapat berbagi ilmu dan terima dengan sambutan yang baik, didukung dengan sepenuhnya walaupun dalam proses memiliki banyak kekurangan. Untuk mengakhiri kegiatan tersebut disampaikan ucapan maaf dan terima kasih dari pihak pendamping maupun terdamping.

\section{PENUTUP}

Kompetensi guru adalah salah satu jaminan kualitas pembelajaran berjalan dengan baik. Kualitas ini dapat ditingkatkan dalam berbagai program. Penguatan kompetensi guru dalam media pembelajaran dengan program autoplay berjalan baik. Aktivitas pelatihan ini diawali dari observasi dan pengenalan madrasah, FGD dan sosialisasi, pelatihan, pendampingan tahap 
Nuruddin, Penguatan Kompetensi Guru ...

pertama, pendampingan tahap kedua, dan Monitoring evaluasi. Adapun hasilnya tentang pengetahuan guru dalam mengoperasikan program tersebut semakin mengalami peningkatan dan dapat dimanfaatkan, dipraktikkan sebagai media pembelajaran di dalam kelas.

\section{DAFTAR PUSTAKA}

Ansori, Multimedia Interaktif dalam Pembelajaran Ilmu Pengetahuan Sosial (IPS). Jurnal Jurusan Pendidikan IPS Ekonomi Society Edisi VII, Mataram: Fakultas Tarbiyah IAIN Mataram, 2012.

Deni Darmawan, Teknologi Pembelajaran. Bandung: PT. Remaja Rosdakarya, 2011.

Munadi Y., Media pembelajaran, Jakarta Selatan: GP Press Group, 2013.

Nasution, Teknologi Pendidikan, Jakarta, Bumi Aksara: 2012.

Ruth Geee \& Trudy-Ann Sweeney. Students' Voices about Learning with's Technology. Journal of Social Sciences.

Rusman, Belajar dan Pembelajaran Berbasis Komputer, (Bandung: Al-Fabeta, 2013).

Seels, B.B. \& Richey, R.C. Teknologi Pembelajaran: Definisi dan Kawasannya (terjemahan). Washington DC: AECT, 1994.

Sukiman, Pengembangan media pembelajaran, Yogyakarta: Pedagogia, 2012.

Sardiman, Interaksi dan motivasi belajar mengajar, Jakarta: PT Raja Grafindo Persada, 2012.

TOSUN Nilgün. Using Information and Communication Technologies in School Improvement. TOJET: The Turkish Online Journal of Educational Technology Volume 10 Issue 1.2011.

Yatim Riyanto, Metodologi Penelitian Pendidikan, Surabaya: SIC, 2001. 